
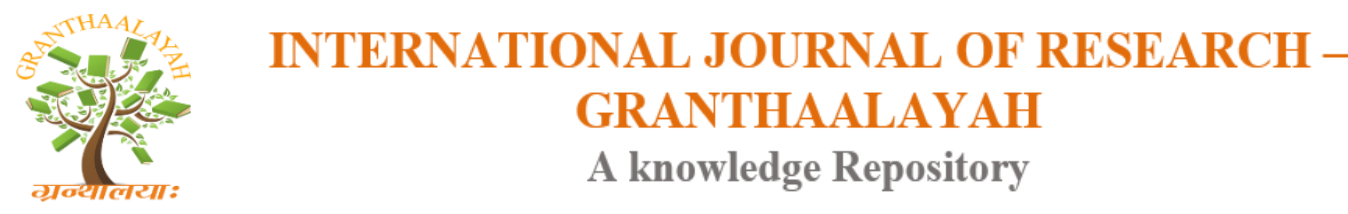

Management

\title{
MANAGEMENT OF PESANTREN IN DEVELOPMENT OF ISLAMIC RELIGION EDUCATION IN JAMBI PROVINCE
}

\author{
Professor Dr. H. Muntholib SM, MS ${ }^{1}$, Professor Dr. Maisah M.Pd. I ${ }^{1}$, Dr. Maryani S.Ag, \\ M.HI ${ }^{1}$ \\ ${ }^{1}$ State Islamic University Sulthan Thaha Saifuddin Jambi
}

\begin{abstract}
Management of Islamic Boarding Schools in the Development of Islamic Education in Jambi Province. Dissertation, Management of Islamic Education / Postgraduate Program of Sulthan Thaha Saifuddin Jambi Islamic University, 2018. The purpose of this study was to find out about Islamic boarding schools that have not been effective in the development of Islamic Education in Jambi Province due to interenal and external factors, want to know and find planning ), organizing, implementing actuating and controlling Islamic boarding schools in the development of Islamic Religious Education in Jambi Province, and wanting to know about the concept of Islamic boarding school development in Islamic Education in Jambi Province. The research approach used is a qualitative approach to the type of case study. It is hoped that the image will be raised about quality, social reality, the perception of the target researchers. Data collection techniques are carried out by means of observation, interviews, and documentation.

The results of the study have not been effective, because of internal and external factors that exist in Islamic boarding schools in the development of Islamic Religious Education. Planning the management of Islamic boarding schools has been based on clear objectives, but not optimal, there is no maximum human and financial resources. Organizing at the Islamic Boarding School is functional, the division of labor has been achieved, the work guidelines are not optimal, and leaders of Islamic boarding schools often delegate to Deputy leaders, because the Kyai are not daily at the pesantren. The management of Islamic boarding schools has cooperated with stakeholders, has not produced graduates above national standards, the committee is not optimal, guidance is not optimal and there are rewards and funmenmen. Supervision of Islamic Boarding School management for maximal absenteeism, optimal information, active computerized system, pesantren website is less active, six-month meetings are less optimal, once a year meeting are optimal, active in motivation and active in clarification and correction.

The concept of development is the design of developing something that already exists in order to improve the quality of more advanced. Recommendations The results of this dissertation research, researchers recommend specifically to: Leaders and Managers of the Zulhijjah Muara Bulian Islamic Boarding School in Batanghari, Syekh Maulana Qori Merangin Leaders and Pesantren, Head of the Ministry of Religion Jambi Province and Leaders of Non-Formal Education Institutions, and Community Organizations.
\end{abstract}

Keywords: Management of Pesantren; Development of Islamic Religion Education. 
Cite This Article: Dr. H. Muntholib, Dr. Maisah, and Dr. Maryani. (2018). "MANAGEMENT OF PESANTREN IN DEVELOPMENT OF ISLAMIC RELIGION EDUCATION IN JAMBI PROVINCE." International Journal of Research - Granthaalayah, 6(9), 407-420. https://doi.org/10.5281/zenodo.1451886.

\section{Introduction}

\subsection{Background}

Development of Islamic Education in Islamic boarding schools requires the process of carrying out certain activities by mobilizing the energy of others, a process that helps formulate organizational policies and goals and requires a process that provides supervision on all matters involved in implementing policies and achieving goals.

From an education perspective, there are known salafi and khalafi pesantren. Salafi Islamic boarding school is a pesantren that maintains the teaching of classical books (yellow books) as the core of teaching using the sorogan method (bandongan). And khalafi has included general lessons in the developed madrasas, or opened the type of public schools in pesantren.

Islamic boarding schools still exist as Islamic educational institutions that have the vision of printing superior human beings. The principle of pesantren is to keep holding a positive tradition, and to keep up with taking new things. Perseolan can be addressed through the principles held by pesantren all this time and of course with an effective, efficient and able to provide parallels as humanity.

The pattern of life in the pesantren is formed naturally through the process of planting values and developing processes of influence influence with the community. Pesantren always experience dynamics that never stop, in line with the social changes that occur. Education in pesantren cannot be separated from management and development problems. Management is a direct translation of the word management which means management, management, or governance. Management is rooted in the verb to manage, which means managing, managing, or managing.

While development is a process of gaining experience, skills and attitudes to become something or achieve success as leaders in their organizations. Therefore, development activities are intended to help someone to be able to handle the problem in the future, by paying attention to the tasks and obligations faced now.

According to Muhaimin, the management standard consists of: a. Develop the implementation of educational activities in schools / madrasas that can produce graduates above national standards, b. Develop other sources of financing including other sources originating from abroad, c. Develop a management system in accordance with the regulations that apply to the budget received by the government, the community or other sources, including other sources from abroad.

School / Madrasah development here can also be applied to the development of Islamic boarding schools, especially the Zulhijjah Islamic boarding school, As'ad Islamic boarding school and 
Syekh Maulana Qori Islamic boarding school. The management standard consists of developing the implementation of educational activities at Islamic boarding schools that can produce graduates above national standards, b. Develop other financing sources that are possible including other sources from abroad, c. Develop a management system in accordance with the regulations that apply to the budget received by the government, the community or other sources, including other sources from abroad.

According to M. Kadarisman, that development is basically development (development) is learning opportunities (learning opportunities), which are designed to help workers / employees / employees or human resources (HR) of the organization / company. Fautino in M. Kadarisman, in his book Management of Human Resources Development, stated that development (development) refers to assisting the development of workers. Such efforts are not limited to efforts to improve the performance of workers in their current jobs.

According to Muhaimin, the development business component includes; The existence of curriculum evaluation and innovation, research, short, medium and long term development planning, seminars, discussions, symposiums, workshops, publishing, role and participation of BP3 , and cooperation with other institutions at home and abroad.

According to Zarqawi Soejati in A. Malik Fadjar, giving a detailed understanding of Islamic education: Islamic Education is a type of education whose establishment and implementation is driven by the desire and passion for the ideals of Islamic values, both reflected in the name of the institution and in activities. which is held. Here the word Islam is placed as a source of value that will be realized in all educational activities. Islamic education is characterized by the formation of akhlakul karimah. Islamic education always emphasizes the formation of conscience, instills and develops divine qualities that are clear and definite, both in relation to humans, human relations with the Creator, and with the natural surroundings.

\section{Theoretical Basis}

\subsection{Management of Pesantren}

According to Evans in his book "The Management and Control of Quality", states that management is a social process to ensure the participation and involvement of a number of people in achieving certain goals. Next said Ben A. Maquad, Robert M. Krone, in his book entitled "Managing For Quality in Higher Education", revealed that management is an activity carried out by a leader. Another view expressed by Neil Ritson in his book entitled Strategic Management, management is serving, helping, helping, directing all activities in achieving certain goals. Perry Timms, in his book entitled HR 2025 Human Resource Management, that management contains about S.M.A.R.T. (Specific, Measurable, Achievable, Relevant, Time-bound), to write management goals and objectives.

Furthermore Manmohan Joshi, in his book entitled Human Resource Management, that management is an activity to move others, and an activity of leading on the basis of something that has been decided in advance. Next said H.A.R. Tilaar, management and administration are two words that can have the same or different meaning. Administration means the same as 
management. In the fields of education, government, hospitals and the military, people generally use the term administration, while industry and companies use the terms management and managers.

In Indonesia, the term pesantren is called Islamic boarding school. Unlike the pesantren, the hut comes from Arabic, which means hotels, dormitories, houses, and simple dwellings. According to Dofier who was quoted by Kasful Anwar Us, the word pesantren was derived from the word santri, with the prefix pe in front and the end of it means the residence of the santri.

The management of pesantren must be broadly based on important elements, among others, the pesantren mission which is in accordance with the philosophy of Islamic education, the functional organizational structure of pesantren, good partnerships and services, pesantren planning and development, HR management and supervision, dynamics in implementing learning strategies, curriculum strengthening practical, efficient management of Learning Resources, management and maintenance of pesantren facilities.

Pesantren management is the management of education to plan education programs and make decisions in the form of concrete actions carried out comprehensively to cover all pesantren needs, vision, mission and goals of pesantren education. Wherein there are regulations, rules and agreements that should not be contrary to regulations, rules, which are higher than the pesantren rules.

\subsection{Development of Islamic Religion Education}

The development area includes many variations of technology used in learning. Moral education, aqidah, and morals must be supported by willingness, compact cooperation and earnest effort from family / household, school and community. Islamic Religious Education is a conscious effort to prepare students to believe, understand, live and practice Islam through guidance, direction or. training by paying attention to the demands to respect other religions in the relationship between religious harmony in society to realize national unity.

The of Islamic education is to form humans who are responsible for themselves and society in order to achieve happiness in the world and the hereafter. Thus, the ultimate goal of Islamic religious education is simply to worship Allah SWT. By trying to carry out all of His commands and leaving His prohibition.

Today, efficiency is a measure in comparing planned input use with actual use of input. If the actual input is used the greater the savings, the higher the level of efficiency, but the smaller the input that can be saved, the lower the level of efficiency. Understanding efficiency here is more oriented to input while the problem of output is less of a concern. Effectiveness is a measure that provides an illustration of how far the target can be achieved. This understanding of effectiveness is more output oriented while the use of input is less of a major concern.

Effectiveness and efficiency are closely related to quality, as a measure that states how far has been fulfilled various requirements, specifications and expectations. Effectiveness is a measure of the success of organizational goals. Effectiveness can also be reviewed from: (1) equitable input; 
(2) high and high quality outputs; (3) knowledge and outputs that are relevant to the needs of developing communities; (4) adequate graduate income.

The process of improving technical skills is that more skilled education personnel will be better able to work and use facilities properly. Education staff will become more skilled if they have adequate skills and experience. Theoritic is a mind or mindset that bases everything from existing theories as the basis for its actions. Making a theory or several at the same time that has a relationship as a foundation for thinking and behaving in the face of or facing problems.

Conceptual is a set of relationships between certain factors that are believed to have an impact on or deliver to a target condition. Employee morale is an inner agreement that arises from within a person or organization to achieve certain goals in accordance with the specified quality. Performance appraisal is the result of work achieved by a person in carrying out tasks that are charged to him based on skill and sincerity and time.

Career planning is the process of increasing individual work abilities achieved in order to achieve the desired career. A condition that indicates an increase in the level or status of a person in his work so that it can meet needs, this is encouraged through personality assessments, especially experience and educational background.

Education as an organized and continuous teaching and learning process designed to communicate a combination of valuable knowledge, skills and understanding for all life activities. Training is a learning process that allows employees to do work that is now in accordance with standards in accordance with standards. Training improves employee performance in work in accordance with current technological developments. Training is also given to new employees or old employees who will renew their skills to be better, according to needs.

Education and training, in general people who have a higher education will have a broader insight, especially appreciation of the importance of productivity. Education here can mean formal, informal or non-formal education. The high awareness of the importance of productivity will encourage the education staff concerned to act productively.

Development is carried out with the aim of improving skills through the exercises needed to be able to carry out their work properly. This activity is considered increasingly important to adjust to the development and increasingly complex work tasks. Mutations apply to giving educational staff opportunities to work in different situations, so mutations are carried out. Mutation is a power management activity

\section{Research Methodology}

The methodology in the research is the whole process of thinking, the value of finding research problems and then elaborating them in a particular theoretical framework, as well as collecting data for empirical testing up to an explanation and conclusion of the problem under study. This study uses a qualitative approach. It is called qualitative because the nature of the data collected is qualitative, not quantitative, using measuring tools. Through this qualitative approach, it is hoped 
that a picture of quality, social reality and perception of research objectives will be raised without being tainted by formal measurements.

Qualitative research is research that emphasizes the quality of the nature of an item / service. The most important thing of goods / services in the form of events / phenomena is the meaning behind the events that can be used as valuable lessons for the development of theoretical concepts. The research approach is very much determined by the research paradigm, which is a way of looking at the research method chosen by researchers. Research approach guides a researcher in carrying out his research from beginning to end.

Creswel in Djaman said that qualitative research is a process of inquiry about understanding based on separate methodological traditions, on examination that exploring a social or human problem. Researchers built a holistic mooring complex examining words, reports, detailing the views of native speakers and conducting studies in a natural setting. Through this approach, it is hoped that the picture of quality, social reality and perception of research objectives will be raised.

Qualitative procedures according to Creswel show a different approach to scientific inquiry than quantitative research methods. Qualitative research uses different philosophical assumptions, inquiry strategies and methods of data collection, analysis and interpretation. Although similar processes, qualitative procedures rely on text and image data, have unique steps in data analysis and draw on diverse strategies of inquiry. Qualitative researchers use theory in research for different purposes.

\section{Research Findings and Analysis}

Empowerment is increasingly needed for network development and collaboration between boarding school carers. It is indeed a struggle that is quite hard for pesantren to develop their existence, so that it is impossible to be left alone without concern from various elements of society and government.

Today we are worried about the various negative influences that exist in the midst of society. Drugs, promiscuity, juvenile delinquency, etc. are threatening friends, neighbors and even our own families. So, at Pondok Pesantren with full supervision from Kyai, Teachers and Management of Islamic Boarding Schools, santri can be fully controlled and protected from these negative influences. With education based on the values of the Islamic Archipelago, Pondok Pesantren becomes an institution that has immunity (immune) from various threats of negative influences. In order for Islamic boarding schools to become institutions that have strong resilience, curriculum planning is needed in a careful, thorough, thorough and detailed manner, as well as considering matters related to the implementation of the curriculum plan. Curriculum planning is a guideline, motivator, and also as a motivation in curriculum implementation.

Santri will be able to integrate the knowledge gained through formal madrasa with religious knowledge gained through pesantren education with its yellow books in daily life. This knowledge will make it easier for students to understand the true meaning of life. Independent living, separate from parents, facilities as they are, will form santri as Muslims who are responsible and accustomed to motivating themselves to be better. 
As a leading educational institution, Islamic boarding schools are able to form the character of the Nusantara Muslim in accordance with Islamic teachings which combine with the values of tradition, culture and local wisdom on all sides of life, giving birth to the Nusantara Muslim Person who loves Islam, fully committed to the Republic of Indonesia Indonesia (NKRI), tolerate diversity, respect pluralism, and always spread peace. After discussing the above problems, the following is a management comparison matrix in the boarding school, which consists of Planning, Organizing, Actuating and Controlling which is often referred to as POAC.

In the operational management of the learning of the Zulhijjah Muara Bulian Batanghari Islamic Boarding School, As'ad Islamic Boarding School in Jambi City, and the Syekh Maulana Qori Merangin Islamic Boarding School based on the Guidance Book of Zulhijjah Muara Bulian Batanghari Islamic Boarding School, As'ad Islamic Boarding School in Jambi City, and the Syekh Maulana Islamic Boarding School Qori Merangin was compiled by the Team of the Zulhijjah Muara Bulian Batanghari Islamic Boarding School, the As'ad Islamic Boarding School in Jambi City, and the Syekh Maulana Qori Merangin Islamic Boarding School.
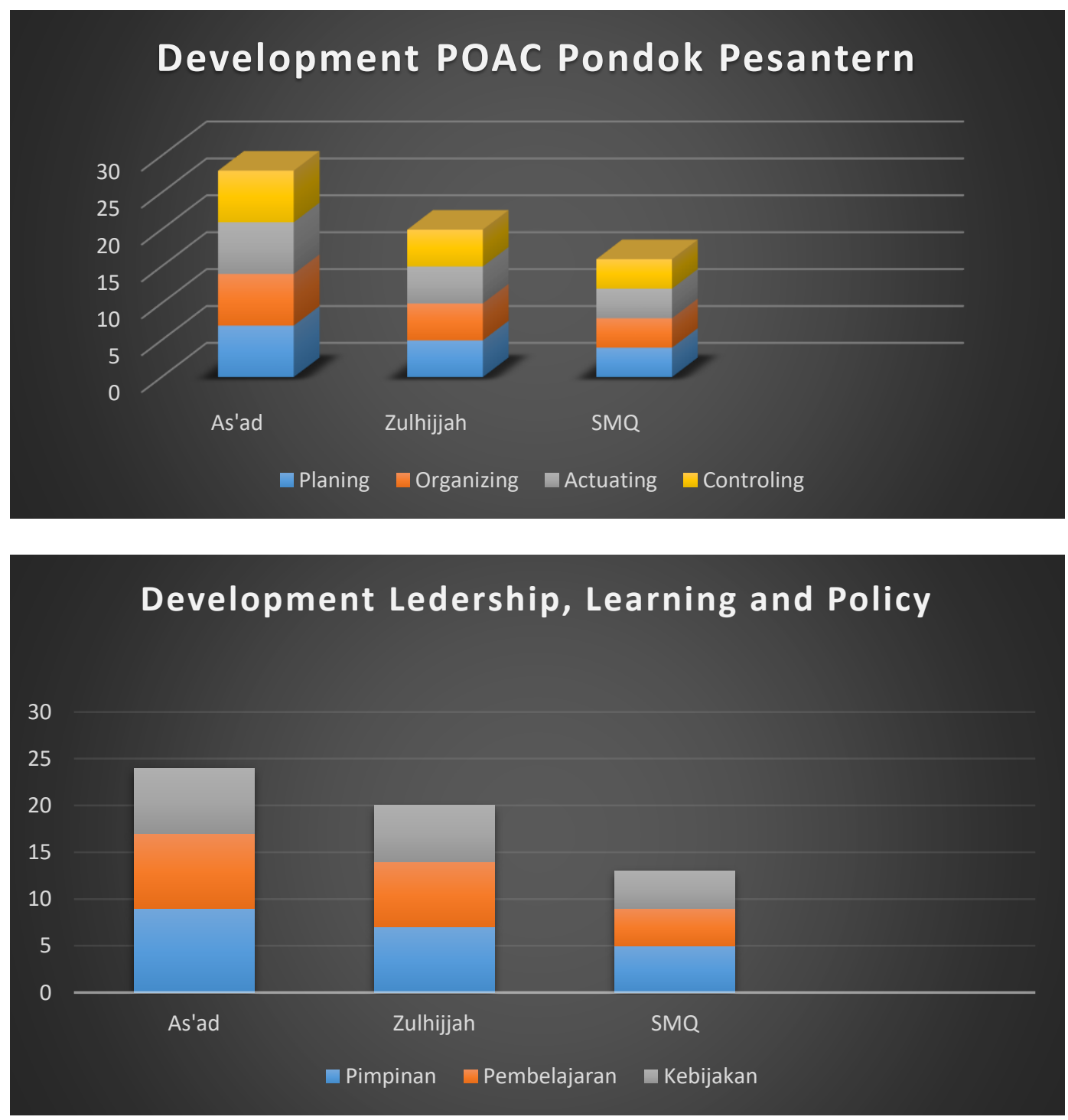

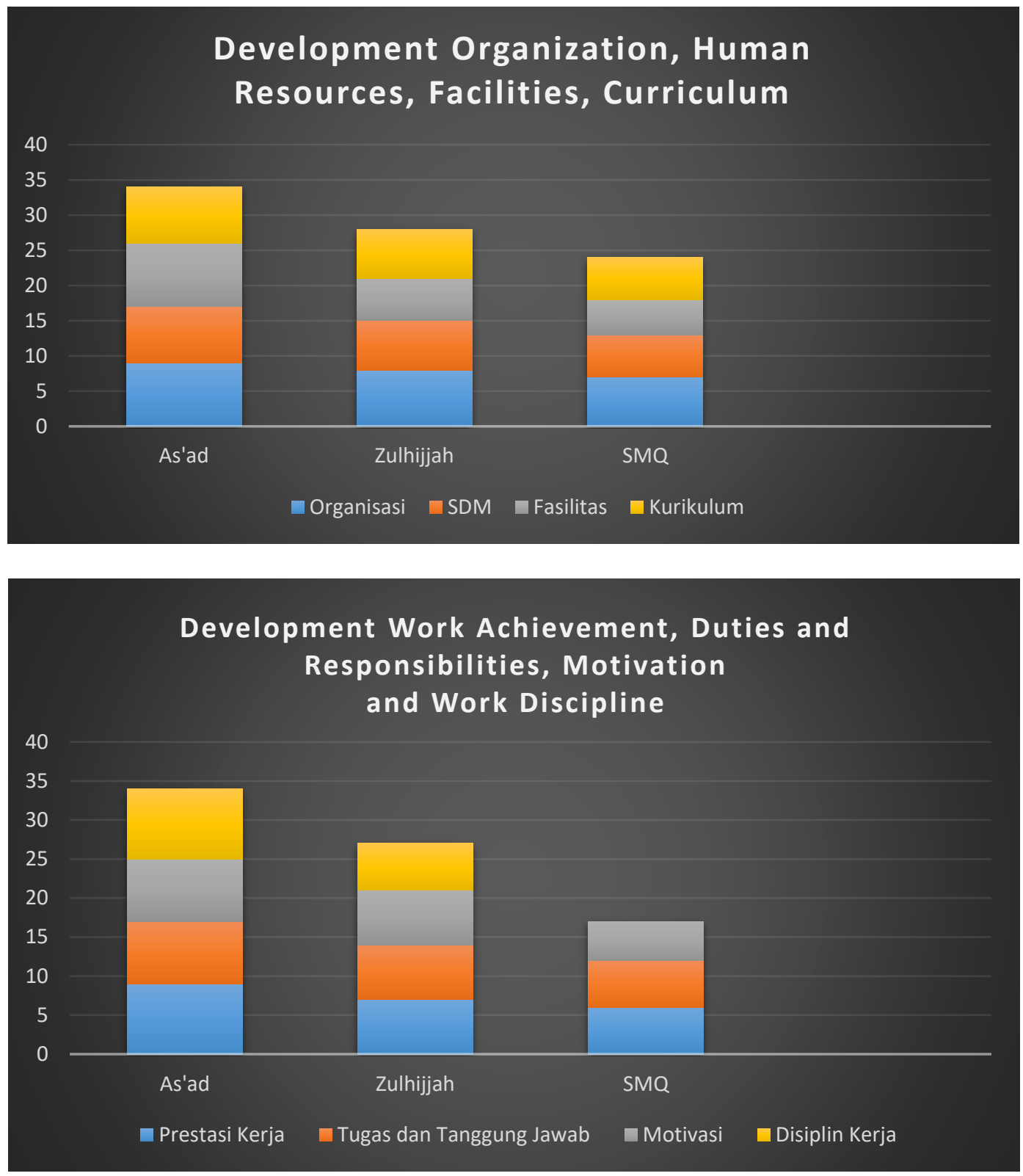

Based on the graph above shows that among the three pesantren namely the Zulhijjah Muara Bulian Batanghari Islamic Boarding School, the As'ad Islamic Boarding School in Jambi City, and the Syekh Maulana Qori Merangin Islamic Boarding School. Both the comparison matrix of peculiarities and excellence in Islamic boarding schools and the comparative matrix for the development of existing Islamic boarding schools.

Then the Zulhijjah Muara Bulian Islamic Boarding School in Batanghari belongs to category 1, the As'ad Islamic Boarding School in Jambi City is in category 2, and the Syekh Maulana Qori Merangin Islamic Boarding School is in category 3. This means that the As'ad Islamic Boarding School in Jambi City is number 1, followed by the Islamic Boarding School Zulhijjah Muara Bulian Batanghari number 2, and the last number 3 is the Islamic Boarding School Syekh Maulana Qori Merangin. The residence of the As'ad Islamic Boarding School in Jambi City occupies the 
number 1 position is indicated in planning things are superior because they are based on clear objectives, detailed, already flexible, there are considerations and there is no duplication of implementation, and the Zulhijjah Muara Bulian Batan Islamic Boarding School ghari occupying the number 2 position is indicated in terms of planning planning already based on clear but less optimal goals. less detailed, flexible, lack of consideration and no duplication of implementation. While the Syekh Maulana Qori Merangin Islamic Boarding School occupies the number 3 position indicated in terms of planning it has been based on clear objectives but not optimal, not detailed, less flexible, lack of consideration and duplication of implementation.

As'ad Islamic Boarding School in Jambi City occupies the number 1 position indicated in terms of superior organizing because it is functional, the division of labor has been achieved, the work guidelines are maximal, flexible, often delegate to Deputy leaders, because Kyai is not every day in pesantren, there is unity the order, and the Zulhijjah Islamic Boarding School Muara Bulian Batanghari occupying the number 2 position was shown to be functional, the division of work had reached a minimum work guidelines had been flexible, often delegating to the vice leadership, because the Kyai were not every day at the pesantren and there was a unity of orders. While the Islamic Boarding School Syekh Maulana Qori Merangin ranked number 3 was shown to be less functional, the division of labor was not achieved, work guidelines were not maximal, less flexible, often delegated to Deputy leaders, because Kyai were not daily in pesantren and lack of unity of orders.

As'ad Islamic Boarding School in Jambi City is ranked number 1 indicated in terms of controlling is superior because absenteeism is maximal, optimal information, active computerized system, Pesantren website is active, six months meeting is optimal once a year is optimal, active in motivation and active in Clarification and correction, and the Zulhijjah Islamic Boarding School Muara Bulian Batanghari occupying the number 2 position was shown to be functional, the division of labor had reached the maximum work guidelines had been flexible, often delegating to the vice leadership, because the Kyai were not every day at the pesantren and there was a unity of orders. While the Islamic Boarding School Syekh Maulana Qori Merangin occupies the number 3 position indicated by less than maximum absenteeism, less optimal information on the computerized system not active, the Pesantren website is less active, six-month meetings are not optimal, and once a year meetings are optimal, active in motivation and active in Clarification and correction.

Kyai Buya Satar is a charismatic person, he is proficient in social matters, but in terms of managing and managing the Islamic boarding school Syekh Maulana Qori is not as up-to-date as in social matters. The results from plantations, such as oil palm plantations, rubber plantations and durian gardens, when viewed from their income, are sufficient to develop the boarding school in a more advanced direction, but the results are not transparent. So that the development of Islamic boarding schools is not optimal.

\section{Conclusion}

Islamic boarding schools have not been effective in the development of Islamic Religious Education in Jambi Province due to interenal and external factors, especially at the Zulhijjah Muara 
Bulian Batanghari Islamic Boarding School, As'ad Islamic Boarding School, Jambi City and the Syekh Maulana Qori Merangin Islamic Boarding School.

Planning the management of Islamic boarding schools in the development of Islamic Religious Education in Jambi Province, especially the Zulhijjah Muara Bulian Islamic Boarding School in Batanghari, the As'ad Islamic Boarding School in Jambi City and the Syekh Maulana Qori Merangin Islamic Boarding School are based on clear, yet optimal, realistic goals. and practical, less detailed, flexible, lack of consideration, there is no maximum resources and funds. Organizing at the Zulhijjah Islamic Boarding School Muara Bulian Batanghari, As'ad Islamic Boarding School in Jambi City and the Islamic Boarding School Syekh Maulana Qori Merangin are functional, the division of labor has been achieved, the work guidelines are not maximal, flexible, unity of orders, and leaders of pesantren often delegate to Deputy leader, because Kyai is not every day at the pesantren. Implementation of the management of Islamic boarding schools in the development of Islamic Religious Education in Jambi Province, especially the Zulhijjah Muara Bulian Islamic Boarding School, As'ad Islamic Boarding School in Jambi City and the Islamic Boarding School Syekh Maulana Qori Merangin has cooperated with stakeholders, has not produced graduates above national standards, meeting, committee is not optimal, procurement of less optimal aspects. actively participate in the ceremony, guidance is not optimal and there is Reward and fun. Management oversight of Zulhijjah Muara Bulian Batanghari Islamic Boarding School, As'ad Islamic Boarding School Jambi City and Islamic Boarding School Syekh Maulana Qori Merangin for maximum absenteeism, optimal information, active computerized system, pesantren website less active, less than six-month meetings, once a year meetings optimal, active in motivation and active in clarification and correction.

The concept of development is applied in Islamic Religious Education in Islamic boarding schools, so ideas, ideas or designs that have been considered mature and successful are further enhanced with the aim of the quality of education that already exists will be increased when this development process continues. The concept of developing Islamic Religion Education, among others: Zulhijjah Islamic boarding school, As'ad and Syekh Maulana Qori is an integrated PAI development concept. Educational institutions managed by Islamic boarding schools have the duty to develop aspects of knowledge and abilities of students. This concept is carried out in stages and multilevel as well as educational institutions in general.

\section{References}

[1] Anonim, Al-Qur'an dan Terjemahnya. Jakarta: Kementerian Agama RI Direktoral Jenderal Bimbingan Masyarakat Islam dan Pembinaan Syariah, 2011.

[2] Aat Syafaat, dkk, Peranan Pendidikan Agama Islam: Dalam Mencegah Kenakalan Remaja, Ed.1, Jakarta: Rajawali Pers. 2008.

[3] Abd. Rachman Assegaf. Aliran Pemikiran Pendidikan Islam: Hadharah Keilmuan Tokoh Klasik sampai Modern, Jakarta: Raja Grafindo Persada. 2013.

[4] Abd. Rasyid Kamaru, Pola Pembinaan Pondok Pesantren Al-Huda Provinsi Gorontalo dalam Meningkatkan Penguasaan Santri terhadap Kitab Kuning, Jurnal Pembaharuan Pendidikan Islam (JPII).

[5] Abdul Majid, Pendidikan Agama Islam Berbasis Kompetensi, Bandung: PT. Remaja Rosdakarya, 2007.

[6] Abin Syamsuddin, Perencanaan Pendidikan Suatu Pendekatan Komprehensif. (Bandung: Remaja Rosdakarya, 2008. 
[7] Ahmad Rohani, Pengelolaan Pengajaran: Sebuah Pengantar Menuju Guru Profesional. Jakarta: Rineka Cipta. 2010.

[8] Ahmad Bin 'Ali Bin Hajar Al 'Asqalani, Fathul BukariBi Syarhi Shahih Al-Bukhari, Juz 13, Dar Al-Fikri: Bairut, 1996.

[9] Akdon, Strategic Management For Educational Management (Manajemen Strategik untuk Manajemen Pendidikan), Cet. 4, (Bandung: Alfabeta, 2011.

[10] Akmal Hawi, Kompetensi Guru Pendidikan Agama Islam, (Jakarta: Raja Grafindo Persada, 2014.

[11] Amin Haedari, Peningkatan Mutu Terpadu Pesantren dan Madrasah Diniyah, (Jakarta: Diva Pustaka, 2008

[12] Amirul Bakhri, Tantangan Pendidikan Agama Islam di Madrasah. Jurnal Madaniyah Edisi VIII, Januari 2015, ISSN 2086-3462.

[13] Aniek Nurhayati, Pesantren Sebagai Institusi Total Pendidikan, Jurnal Fakultas Ushuluddin IAIN Sunan Ampel, 2008.

[14] Anita Pickerden, Planning and Managing your work based project, A Guide for student $1{ }^{\text {st }}$ Edition, (Bookboon.com. ISBN 978-87 403-1044-3. 2015), hal. 11-15.

[15] Anonim. Pendidikan Agama Islam dalam Perspektif Multikul-turalisme, Cetakan 1, Jakarta: Balai Penelitian dan Pengembangan Agama. 2009.

[16] Azyumardi Azra. Pendidikan Islam Tradisi dan Modernisasi Menuju Milenium Baru. Jakarta: Logos Wacana Ilmu. 2009.

[17] Badarus Syamsi. Akulturasi Pesantren Jawa di Jambi, Jurnal Kontektualita, Vol. 28, No. 1, Institut Agama Islam Negeri (IAIN) Sulthan Thaha Saifuddin Jambi. 2013.

[18] Bambang Rudito, dkk. Social Mapping. Bandung: Rekayasa Sains. 2013.

[19] Bambang Ismaya. Pengelolaan Pendidikan. Bandung: PT. Refika Aditama. 2015.

[20] Basrowi dan Suwandi. Memahami Penelitian Kualitatif. Jakarta: Rineka Cipta. 2008.

[21] Ben A. Maquad. Robert M. Krone, Managing for Quality in Higher Education: A Systems Perspective, (bookboon.com. 2012), ISBN 978-87-403-0205-9. hal. 148. Lihat juga Irham Fahmi, Manajemen, Teori, Kasus dan Solusi. Bandung: Al-Fabeta, 2011.

[22] Bukhari Umar. Ilmu Pendidikan Islam, Ed. 1, Cet. 1, Jakarta: Amzah. 2010.

[23] Buku Panduan Opentren Madrasah Aliyah Pondok Pesantren As'ad Jambi tahun 2016.

[24] Creswel, John W. Research Design Qualitative, Quantitative, and Mixed Methods, Singapore: Sage Publications Asia-Pacific Pte.Ltd. 2009.

[25] Deden Makbuloh, Manajemen Mutu Pendidikan Islam: Model Pengembangna Teori Aplikasi Sistem Penjaminan Mutu. Jakarta: Raja Grafindo Persada. 2011.

[26] Deni Darmawan, Inovasi Pendidikan: Pendekatan Praktik Teknologi Multimedia dan Pembelajaran Online. Bandung: Remaja Rosdakarya. 2012.

[27] Diding Nurdin. Pengelolaan Pendidikan dari Teori Menuju Implementasi. Jakarta: Raja Grafindo Persada. 2015.

[28] Dinn Wahyudin. Manajemen Kurikulum. Bandung: PT. Remaja Rosdakarya. 2014.

[29] Djam'an Satori dan Aan Komariah. Metodologi Penelitian Kualitatif. Bandung: Alfabeta. 2009.

[30] Egar G. Guba dan Yvonna Lincoln. Naturalistic Inquiri. New Delhi: Sage Publication Inc. 2009.

[31] Fatah A. Dimensi-Dimensi Pendidikan Islam. Malang: UIN-Malang Press. 2008.

[32] Florian Pohl. Islamic Education and civil Society: Reflections on the Pesantren Tradition in Contemporary Indonesia. Journal. 2006.

[33] Fuaduddin. dkk. Melacak Nalar Radikal: Kasus Pesantren Al-Mukmin Ngruki. Jakarta: Gaung Persada Press, 2007.

[34] George R. Terry. Prinsip-Prinsip Manajemen. Jakarta: Bumi Aksara. 2009.

[35] Haedari. Amin dan Ishom El-Saha, Peningkatan Mutu Terpadu Pesantren dan Madrasah Diniyah. Jakarta: Diva Pustaka. 2008.

[36] Haidar Putra Daulay. Dinamika Pendidikan Islam di Asia Tenggara. Jakarta: Rineka Cipta. 2009.

[37] Hamdani Hamid. Pengembangan Kurikulum Pendidikan. Bandung: Pustaka Setia. 2012.

[38] Hamzah B. Uno. Perencanaan Pembelajaran. Cet. 7. Jakarta: Sinar Grafika. 2011. 
[Muntholib et. al., Vol.6 (Iss.9): September 2018]

(Received: August 28, 2018 - Accepted: September 27, 2018)
ISSN- 2350-0530(O), ISSN- 2394-3629(P)

DOI: 10.5281/zenodo.1451886

[39] Hanif Ismail. Dkk. Sistem Pengendalian Manajemen Konsep dan Aplikasi. Jakarta: Mitra Wacana Media. 2009.

[40] Hasani Ahmad Said. Studi Islam I Kajian Islam Kontemporer. Ed. 1. Cet. 1. Jakarta: Rajawali Pers. 2016.

[41] Hendri Tanjung. Manajemen Syari'ah dalam Praktik 9 Nabi dan Rasul. Jakarta: PT. Elex Media Komputindo. 2014.

[42] Husaini Usman. Manajemen Teori, Praktik, dan Riset Pendidikan. Ed. 3. Cet. 2. Jakarta: PT. Bumi Aksara, 2010.

[43] I Gede Ratnaya. Pengembangan Desain Pembelajaran Mobile Learning Management System pada Materi Pengenalan Komponen Jaringan. Jurnal penelitian dan Pengembangan Pendidikan 5 (3), 314-324 JPPP. Lembaga Penelitian Undiksha. 2011.

[44] Ian Pownall. Efective Manajement Decision Making An Introduction. bookboon.com, 2012. ISBN 978-87-403-0120-5.

[45] Ibnu Katsir. Terjemah Singkat Tafsir Ibnu Katsir. Jilid 4. Surabaya: PT. Bina Ilmu. 2009.

[46] Iwan Kuswandi. Konsepsi Pesantren Kiai Idris Jauhari Dalam Perspektif Relasi Fikih. Tasawuf dan Pendidikan. Madura: Disertasi. 2012.

[47] J. Winardi. Manajemen Perilaku Organisasi. Jakarta: Kencana. 2008.

[48] James R. Evans/William M. Lindsay. The Management and Control of Quality. Seventh Edition. USA: South-Western Cengage Learning. 2008.

[49] James Spradley. Participant Observation. New York: Holt Rinehart and Winston. 2008.

[50] Jhonm. Bryson. Perencanaan Strategis. Yogyakarta: Pustaka Pelajar. 2007.

[51] Kasful Anwar Us. Kepemimpinan Pesantren: Menawarkan Model Kepemimpinan Kolektif dan Responsif. Jambi: Suthan Thaha Saifuddin Press. 2011.

[52] Lanny Octavia. dkk. Pendidikan Karakter Berbasis Tradisi Pesantren. Jakarta: Rumah Kitab. 2014.

[53] Larry M. Walther and Christopher J. Skousen, Managerial and Lost Accounting. Ventus Publishing ApS, Bookboon.com: 2009. ISBN 978-87-7681-491-5.

[54] Lexy J. Moleong. Metodologi Penelitian Kualitatif. Bandung: PT Remaja Rosdakarya. Offset. 2011.

[55] M. Quraish Shihab. Tafsir Al-Misbah jilid 6. Jakarta: Lentera Hati. 2008.

[56] M. Atho Muzhar. Meninjau Kembali Studi Islam Dari Teori Ke Praktek, Jurnal Indo-Islamika. Volume 2, Nomor 1. 2012/1433.

[57] M. Kadarisman. Manajemen Pengembangan Sumber Daya Manusia. Jakarta: Rajawali Pers. 2013.

[58] M. Umar. Pengelolaan Zakat oleh Badan Amil Zakat Nasional (BAZNAS) dalam menunjang Pendidikan di Kota Jambi, Disertasi TA 2016.

[59] M. Yusuf Hamdani, Manajemen Pendidikan Pondok Pesantren Studi Kasus pada Pondok Pesantren Aji Mahasiswa Al-Mukmin di Krapyak Wetan Yogyakarta. Yokyakarta: Disertasi UIN Sunan Kalijaga, 2009.

[60] Maisah. Manajemen Starategik dalam Persfektif Pendidikan Islam. Jambi: Salim Media Indonesia. 2016.

[61] Malik Fadjar. Holistika Pemikiran Pendidikan. Jakarta: PT. Raja Grafindo Persada. 2007.

[62] Manmohan Joshi. Human Resource Management1 st edition, Bookboon.com: 2013. ISBN 978-87403-0393-3.

[63] Martinis Yamin \& Maisah. Manajemen Pembelajaran Kelas Strategi Meningkatkan Mutu Pembelajaran. Cet. 2. Jakarta: Gaung Persada Press. 2012.

[64] Merle J. Schwartz. Effective Character Educatio. Newyork: McGraw-Hill. 2008.

[65] Miftah Thoha, Kepemimpinan dalam Manajemen, Ed. akarta: Rajawali Pers. 2012.

[66] Muhaimin. Manajemen Pendidikan Aplikasinya dalm Penyusunan Rencana Pengembangan Sekolah/MadrasahJakarta: Kencana. 2009.

[67] Mujamil Qomar, Manajemen Pendidikan Islam, (Malang: Erlangga, 2008.

[68] Mukhtar. Metode Praktis Penelitian Dekriptif Kualitatif, Jakarta: Referensi. 2013. 
[69] Mulyasa, E, Standar Kompetensi dan Sertifikasi Guru, (Bandung: Remaja Rosdakarya, 2008), hal. 77.

[70] Mulyasa, E. Menjadi Kepala Sekolah Profesional, (Bandung: Remaja Rosdakarya, 2009.

[71] Musthofa Harun dkk, Khazanah Intelektual Pesantren, Cet. I. Jakarta: CV. Maloho Jaya Abadi, 2009.

[72] Muzayyin Arifin. Kapita Selekta Pendidikan Islam. Jakarta: Bumi Aksara, 2009.

[73] Nana Sudjana. Penilaian Hasil Belajar. Bandung: Remaja Rosda Karya. 2012.

[74] Neil Ritson, Strategic Management, 2nd edition, Bookboon.com: 2013. ISBN 978-87-403-0506-7.

[75] Andrew J. Dubrin, Essential of Manajement, (Ohio: South Western, tt), hal.2. Dan Lihat juga Martinis Yamin, Paradigma Baru Pembelajaran, (Jakarta: Referensi, 2013.

[76] Nurudin. dkk, Ujian Nasional di Madrasah: Persepsi dan Aspirasi Masyarakat. Jakarta: Gaung Persada Press. 2007.

[77] Oemar Hamalik, Manajemen Pengembangan Kurikulum, Cet. 5, Bandung: Remaja Rosdakarya. 2012.

[78] Pepen Supendi, Karakteristik Kepemimpinan Kiai dalam Memelihara Budaya Organisasi dan Kontribusinya terhadap Mutu Pendidikan Pesantren, Ringkasan Disertasi Pepen.pdf. A. R. 933.15 B.

[79] Peraturan Pemerintah Republik Indonesia Nomor 55 Tahun 2007 tentang Pendidikan Agama dan Pendidikan Keagamaan.

[80] Peraturan Menteri Agama Republik Indonesia Nomor 13 Tahun 2014 tentang Pendidikan Keagamaan Islam.

[81] Peraturan Menteri Agama Republik Indonesia Nomor 3 Tahun 2012 tentang Pendidikan Agama Islam.

[82] Perry Timms, HR 2025 Human Resource Management, 1 st edition, Bookboon.com: 2013. ISBN 978-87-403-0506-5.

[83] Rahmat Rais, Modal Sosial Sebagai Strategi Pengembangan Madrasah: Studi Pengembangan Madrasah pada MAN 1 Surakarta, (Jakarta: Litbang \& Diklat Departemen Agama RI, 2009.

[84] Ramayulis, Ilmu Pendidikan Islam, (Jakarta: Kalam Mulia, 2007), hal. 259.

[85] Ridwan. Skala Pengukuran Variabel-Variabel Penelitian. Bandung: Alfabeta. 2012.

[86] Rohiat, Manajemen Sekolah: Teori Dasar dan Praktik, Cet. 4, (Bandung: Refika Aditama, 2012.

[87] Rusdiana dkk, Asas-Asas Manajemen Berwawasan Global, (Bandung: Pustaka Setia, 2014.

[88] Siti Raudhatul Jannah, Pengembangan Karir Tenaga Pendidik Teori dan Aplikasi, Yogyakarta: Magnum Pustaka Utama, 2016.

[89] Soebahar, Abd.Halim, Modernisasi Pesantren, Yogyakarta; Lkis, 2013.

[90] Soekidjo Notoatamodjo, Pengembangan Sumber Daya Manusia, (Jakarta: PT. Rineka Cipta. 2008.

[91] Sofwan, Pengaruh Etos Kerja, Kepemimpinan Transformatif dan Budaya Pesantren terhadap Efektifitas Pengelolaan Pesantren di Provinsi Jambi. Disertasi: UIN STS Jambi. 2016.

[92] Sondang P. Siagian, Manajemen Sumber Daya Manusia, Ed. 1. Cet. 21 Jakarta: Bumi Aksara, 2013.

[93] Sri Wahyuni Tanshzil, Model Pembinaan Pendidikan Karakter pada Lingkungan Pondok Pesantren dalam Membangun Kemandirian dan Disiplin Santri (Sebuah Kajian Pengembangan Pendidikan Kewarganegaraan). Portal Jurnal UPI, vol. 14 No. 2 Oktober 2014, 2012.

[94] Sugiono, Metode Penelitian Pendidikan Pendekatan Kunatitatif, Kualitatif dan R \& D., Bandung: Alfabeta. 2009.

[95] Suharsimi Arikunto dan Lia Yuliana. Manajemen Pendidikan. Yogyakarta: Aditya Media. 2009.

[96] Sulistyorini. Manajemen Pendidikan Islam. Yogyakarta: Teras. 2009.

[97] Suparlan. Manajemen Berbasis Sekolah: dari Teori sampai dengan Praktik, Ed. 1. Cet. 2. Jakarta: Bumi Aksara. 2014.

[98] Suparno Eko Widodo, Manajemen Pengembangan Sumber Daya Manusia. Jakarta: Jaya Medika. 2014. 
[99] Sya'ie. Akhmad Najibul Khairi, Strategi Manajemen Pesantren Di Malang Menuju Pesantren Mandiri: Studi Analisis Aplikasi Konsep Total Quality Manajemen Di Pesantren. 2013. Penelitian Individu.

[100] Syaiful Sagala, Administrasi Pendidikan Kontemporer.Bandung: Alfabeta, 2009.

[101] Tilaar A. R. Membenahi Pendidikan Nasional, Cet. 2, (Jakarta: Rineka Cipta, 2009.

[102] Trianto. Model Pembelajaran Terpadu: Konsep, Strategi, dan Implementasinya dalam Kurikulum Tingkat Satuan Pendidikan (KTSP). Jakarta: Bumi Aksara. 2011.

[103] Udin Syaefudin Sa'ud dan Abin Syamsuddin. Perencanaan Pendidikan Suatu Pendekatan Komprehensif, Bandung: Pt Remaja Rosdakarya. 2008.

[104] Umar Sidiq, Pengembangan Standarisasi Pondok Pesantren. Jurnal Nadwa Pendidikan Islam, Vol. 7. Nomor 1. April 2013.

*Corresponding author.

E-mail address: sumarto.manajemeno@gmail.com 